\title{
The Bacterial Flora in A Healthy Oral Cavity
}

\author{
Ambarkova Vesna* \\ Department for preventive and pediatric dentistry, University Ss. Cyril \& Methodius, Republic of Macedonia
}

Submission: June 14, 2018 Published: September 12, 2018

*Corresponding author: Vesna Ambarkova, PhD, MSc, DDS, University St. Cyril and Methodius, Faculty of Dental Medicine, Department of Paediatric and Preventive Dentistry, Mother Theresa 17 University Dental Clinic Center Sv. Pantelejmon, Skopje 1000, Republic of Macedonia; Tel: +38970686333; Email: vesna.ambarkova@gmail.com

\section{Review}

The mouth is a habitat of a large, diverse and complex microbial environment. Different types of bacteria live on different surfaces in the mouth, accumulating the hard and soft tissue in the form of biofilms, affecting the ecological filaments of the dental surface and the gingival epithelium [1,2]. More than 750 types of bacteria or phylotypes, of which $50 \%$ are not yet cultivated, are detected in the oral cavity. They developed mechanisms of host adaptation and mechanisms of modification and avoidance to the host immune response. But the human immune system constantly monitors their growth and reproduction, preventing their invasion of the surrounding tissue and the development of disease. In fact, there is a dynamic equilibrium between the biocommunities of the bacteria and the human immune system, and oral health depends on the integrity of all-natural barriers that normally block the activity of microorganisms.

The oral cavity of the newborn does not contain bacteria but is rapidly colonized with Streptococcus salivarius. With the onset of the first teeth, Streptococcus mutans and Streptococcus saguinis appear. Various anaerobes predominantly inhabit gingival sulcus, while bacteroids and spirochaetes appear in the mouth during puberty [2]. The concentration of bacteria in the saliva is about $108 / \mathrm{ml}$ with $90 \%$ of anaerobic bacteria, where the predominant organism is Veillonella parvula [3]. In a healthy oral cavity, Streptococcus, Pepto streptococcus, Veillonella and dipheroids account for more than $80 \%$ of the total microbial flora. Many clinically significant oral anaerobic gram-negative bacilli previously included within the "oral Bacteroides" group are now reclassified as Porphyromonas or Prevotella species [4].

Oral cavity cannot be considered a unique uniform environment. Although representatives of various types of microorganisms may be isolated from several areas of the mouth, however, certain organisms tend to colonize certain predilection sites. As for example Fusobacterium, pigmented Prevotella, and anaerobic spirochaetes are concentrated in the gingival sulcus. Bacterial adherence and interaggregate, local environmental conditions, such as the presence of oxygen, $\mathrm{pH}$, and other host factors seem to regulate these unique patterns of colonization and affect the composition of the oral flora. As and Pasteur research has confirmed that different bacteria live on different surfaces in the mouth because of specific bacterial cell adhesion molecules that are associated with complementary specific oral surface receptors $[5,6]$.

Some of the bacteria in the mouth are responsible for oral diseases such as caries and periodontal disease, which are one of the most common diseases in humans. At least $35 \%$ of adults between 30-80 years in the United States have some form of periodontal disease $[7,8]$. Specific oral bacterial species are also considered to have a role in systemic diseases such as bacterial endocarditis [9], aspiration pneumonia [10], osteomyelitis in children [11] and cardiovascular diseases [12,13].

Bacteria in the oral cavity have evolved over time, with the aim of protecting individual bacterial organisms, in supra and sub-gingival bacterial communities, that is, plaque. The dental plaque is a dense, non-mineralized, complex mass of bacterial colonies that live in a gel-intermixing matrix and adheres to the tooth. Contains bacterial cells, salivary polymers and bacterial extracellular products [11]. The flora of the plaque formation involves the presence of $2.5 \times 107$ aerobic bacteria/mg plaque and about $4.6 \times 107$ anaerobic bacteria/mg plaque [14]. The dental plaque begins to accumulate within 24 hours without regular tooth brushing. The dental plaque has an extra-polysaccharide that surrounds it and protects it from the penetration of an antibiotic. After the formation of the dental plaque, visible gingival inflammation develops in 2-4 days due to the production of various metabolites such as endotoxins, lipoteic acid, mucopeptides, metabolic products, and proteolytic agents such as hyaloronidase, and chondroitinase that can reach the gingival tissue directly or act indirectly through the stimulation of the immune system which further leads to further destruction.

Plaque accumulation can be stimulated by increased production of gingival cervical fluid that contains growth factors of various bacteria including gram negative anaerobes such as Porphyromonas gingivalis, Prevotella melaninogenica and Fusobacterium nucleatum. 


\section{References}

1. Aas JA, Paster BJ, Stokes LN, Olsen I, Dewhirst FE (2005) Defining the normal bacterial flora of the oral cavity. J Clin Mikrobiol 43(11): 57215732.

2. Rogers AH (2008) Molecular Oral Microbiology. Caister academic Press $33(4)$.

3. Chow AW (2005) Infections of the oral cavity, neck and head. In: Mandell GL, Bennett JE, Dolin R (Eds.), Principles and Practice of Infectious Diseases, ( $6^{\text {th }}$ edn), Churchill Livingstone, Philadelphia, USA, p. 787.

4. Jousimies SH, Summanen P (2002) Recent taxonomic changes and terminology update of clinically significant anaerobic gram-negative bacteria (excluding spirochetes). Clin Infect Dis 35(1): 17-21.

5. Gibbons RJ (1989) Bacterial adhesion to oral tissues: a model for infectious diseases. JDent Res 68(5): 750-760.

6. Gibbons RJDM Spinell, Z Skobe (1976) Selective adherence as a determinant of the host tropisms of certain indigenous and pathogenic bacteria. Infect Immun 13(4): 1299.

7. Albandar JM, Brunelle JA, Kingman A (1990) Destructive periodontal disease in adults 30 years of age and older in the United States, 19881994. J Periodontol 70(1): 13-29.

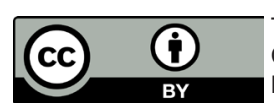

This work is licensed under Creative Commons Attribution 4.0 License DOI: 10.19080/ADOH.2018.09.555773
8. Berbari EF, Cockerill FR, Steckelberg JM (1997) Infective endocarditis due to unusual or fastidious microorganisms. Mayo Clin Proc 72(6): 532-542.

9. Scannapieco FA (1999) Role of oral bacteria in respiratory infection. J Periodontol 70(7): 793-802.

10. Lebel E, Rudensky B, Karasik M, Itzchaki M, Schlesinger Y (2006) Kingella kingae infections in children. J Pediatr Orthop B 15(4): 289292.

11. Daniluk T, Tokajuk G, Cylwik-Rokicka D, Rozkiewicz D, Zaremba ML, et al. (2006) Aerobic and anaerobic bacteria in subgingival and supragingival plaques of adult patients with periodontal disease. Adv Med Sci 51(1): 81-85.

12. Beck J, Gracia R, Heiss G, Vokonas PS, Offenbacher S (1996) Periodontal disease and cardiovascular disease. J Perodontal 67: 1123-1137.

13. Wu T, Trevisan M, Genco RJ, Dorn JP, Falkner KL, et al. (2000) Periodontal disease and risk of cerebrovascular disease: the first national health and nutrition examination survey and its follow- up study. Arch Intern Med 160(18): 2749-2755.

14. Spratt D (2003) Dental plaquae and bacterial colonization. In: Jass J, Surman S, Walker J (Eds.), Medical biofilms. John Wiley and Sons Ltd, USA, pp. 175-198.

\section{Your next submission with Juniper Publishers will reach you the below assets}

- Quality Editorial service

- Swift Peer Review

- Reprints availability

- E-prints Service

- Manuscript Podcast for convenient understanding

- Global attainment for your research

- Manuscript accessibility in different formats

( Pdf, E-pub, Full Text, Audio)

- Unceasing customer service

Track the below URL for one-step submission https://juniperpublishers.com/online-submission.php 